\title{
Ufer grounding system to minimize risk of lightning strike using concrete mixed with bentonite and coconut fiber
}

\author{
Yul Martin ${ }^{*}$, Diah Permata ${ }^{2}$, Annisa Ulya ${ }^{3}$, Dikpride Despa $^{4}$, Marwansyah $^{5}$, Ali Rahmat $^{6}$ \\ 1, 2, 3, 4,5 Department of Electrical Engineering, Faculty of Engineering, University of Lampung, Indonesia \\ ${ }^{6}$ The United Graduate School of Agriculture Science, Gifu University, Japan \\ *Corresponding Address: yul.martin@eng.unila.ac.id
}

\begin{tabular}{|c|c|}
\hline Article Info & ABSTRACT \\
\hline Article history: & The increasing frequency of lightning strikes endangers human safety and life. \\
\hline $\begin{array}{l}\text { Received: January } 14^{\text {th }}, 2020 \\
\text { Accepted: April } 16^{\text {th }}, 2020 \\
\text { Published: April } 30^{\text {th }}, 2020\end{array}$ & $\begin{array}{l}\text { The grounding system was introduced to face the lightning strikes. This } \\
\text { research aimed to understand the changes of grounding resistance value using } \\
\text { concrete mixed with bentonite and coconut fiber. The research was conducted } \\
\text { in the Laboratory of Electrical Engineering, University of Lampung. The }\end{array}$ \\
\hline Keywords: & $\begin{array}{l}\text { research was started from October } 2017 \text { to April } 2018 \text {. This research used the } \\
\text { Ufer grounding system. Concretes with }(25 \times 25 \times 30) \mathrm{cm}^{3} \text { in volume were }\end{array}$ \\
\hline $\begin{array}{l}\text { Bentonite; } \\
\text { Coconut fiber; } \\
\text { Concrete; } \\
\text { Grounding resistance; } \\
\text { Ufer grounding }\end{array}$ & $\begin{array}{l}\text { planted at a depth of } 50 \mathrm{~cm} \text { with copper-coated electrodes that were } 16 \mathrm{~mm} \text { in } \\
\text { diameter. } 4 \text { concrete was produce with different component } \mathrm{T} 1=\text { concrete, } \\
30 \% \text { bentonite, T2= concrete, } 30 \% \text { bentonite, } 1.5 \% \text { coconut fiber, T3= } \\
\text { concrete, } 30 \% \text { bentonite, } 0.75 \% \text { coconut fiber, T } 4=\text { concrete }+1.5 \% \text { coconut } \\
\text { fiber. The results show that the lowest grounding resistance values were } \\
45.896 \Omega \text { on the concrete with bentonite: cement: sand: gravel }=0.3: 0.7: 2: \\
4 \text {. By adding } 1.5 \% \text { coconut fiber, the grounding resistance value is } 3.5 \text { times } \\
\text { smaller than the grounding resistance values of the soil }(161.2 \Omega) \text {. Adding } \\
\text { bentonite and coconut fiber can decrease the grounding resistance values. }\end{array}$ \\
\hline
\end{tabular}

(C) 2020 Physics Education Department, UIN Raden Intan Lampung, Indonesia.

\section{INTRODUCTION}

Nowadays, global climate change was causing extreme weather conditions (Lehmann et al., 2015; Ogunbode et al., 2019; Rahmat \& Mutolib, 2016); one of them is increasing the frequency of lightning strike. In the high magnitudes of current and voltage could destroy the electrical device or properties and endanger to human safety and life. Moreover, lightning can damage the building and can be burning in that affected area. The technology to avoid lightning stroke and protect the buildings is needed. The grounding system was introduced to face the lightning strike (Al-Ammar et al., 2010; Ghania, 2019).

Grounding or earthing is a process of connecting any electrically part to the mother earth, of which the potential is treated as the zero references. That is a vital part of the fields of lightning protection, power, and communication system. In the lightning protection system, the grounding acts as the interface between natural transient phenomena from the cloud (lightning) and the masses of soil. The function of the grounding system is to divert the flow of charge to the soil masses as fast as possible (Gomes et al., 2014; Halim et al., 2019).

Current research, studying of grounding materials use conductive concrete as it had good mechanical properties, electrical conductivity, and corrosion resistance. The resistivity of conductive concrete was lower than the soil (Ma et al., 2014). The contact area between the soil and electrode could be enlarged by put down conductive concrete around the metal grounding electrodes, and the grounding resistance could be reduced (Sun, 2001). Currently, conductive concrete 
was mainly used as auxiliary grounding material in the grounding system by molding around the vertical grounding body through a directly molding around the ground/ soil surface (Jin-rong \& Yong-ming, 2008; Tian et al., 2012).

Martin (2019) reported soil mixed with $25 \%$ gypsum, soil mixed with $50 \%$ gypsum, and soil mixed with $75 \%$ gypsum resulted in reduction grounding resistance respectively $153.56 \Omega, 169.91 \Omega, 157.2 \Omega$. The best combination is soil mixed with 50\% gypsum. Moreover, Martin et al. (2019) reported, grounding resistance using bentonite can reduce grounding resistance value until $68 \%$ or $65 \Omega$ while the soil was $206 \Omega$.

Various proportions of bentonite to mixed into concrete for Ufer grounding was investigated. The lowest grounding resistance with the least fluctuation as well is proportioned $30 \%$ bentonite-concrete mixed (Lim et al., 2016).

However, research about the grounding resistance system using conductive concrete with adding with addictive material are limited. This research will describe the grounding resistance system using conductive concrete with adding addictive material such as bentonite and coconut fiber.

\section{METHODS}

\section{Experimental design}

The research was conducted in the Laboratory of Electrical Engineering, Faculty of Engineering, University of Lampung. The research was started from October 2017 to April 2018. This research use model of the "Ufer grounding" system.

This research design uses concrete that is the volume $(25 \times 25 \times 30) \mathrm{cm}^{3}$ and planted at a depth of $50 \mathrm{~cm}$ and uses copper-coated electrodes that are $16 \mathrm{~mm}$ in diameter and 50 $\mathrm{cm}$ in length. Four concrete produced with different treatment/ additional components (additive material), there are $\mathrm{T} 1=$ Grounding hole with concrete and $30 \%$ bentonite, $\mathrm{T} 2=$ Grounding hole using concrete (bentonite: cement: sand: gravel $=0.3: 0.7: 2: 4)$ and the addition of coconut fiber waste $1.5 \%, 300 \mathrm{~g}$,
T3=Grounding hole using concrete (bentonite: cement: sand: gravel $=0.3: 0.7: 2$ : 4 ) and the addition of coconut fiber waste $0.75 \%$ which is $150 \mathrm{~g}$, T4= Grounding hole using concrete (cement: sand: gravel $=1: 2$ : 4) and the addition of coconut fiber waste $1.5 \%$, which is $300 \mathrm{~g}$. The preliminary data was collected using pure concrete without additives material. Measuring the grounding resistance value using pure concrete was carried out five months before measuring the grounding resistance value from 4 different compositions; the value of pure concrete resistance can be used as standard.

Comparison of material for pure concrete is (cement: sand: gravel $=1: 2: 4$ ). Measuring the grounding resistance value using the Kyoritsu model 4105A (Hutauruk, 1991), see figure 1 . The measurement of the grounding resistance value in this study is using the 3 points method for standard data (Nasional, 2002, 2008). Figure 2. shows how earth grounding measurements use the 5 points method.

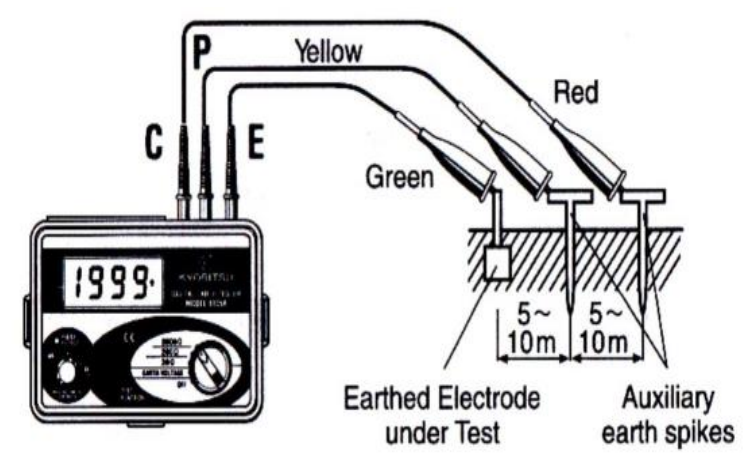

Figure 1. Measuring the grounding resistance value using Kyoritsu model 4105A (Hutauruk, 1991).

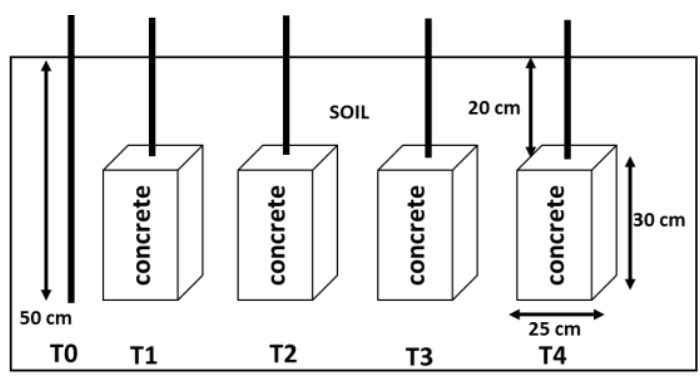

Figure 2. The Visualization of grounding holes with concrete mixed with additives material 
Calculating percentage changes in grounding resistance value following below equation (Martin et al., 2019; Hutauruk, 1991).

\% Change $\mathrm{R}=\left(\mathrm{R} \_\mathrm{X}-\mathrm{R} \_\mathrm{Y}\right) / \mathrm{R} \_\mathrm{X} \times 100 \%$

Where, $\mathrm{Rx}=$ grounding resistance value without additives, $\mathrm{Ry}=$ grounding resistance value with additives.

\section{Characteristic of the material Concrete}

Concrete is a homogeneous mixture between cement, water, and aggregate. The characteristics of concrete are high crushed stress and low tensile stress. Concrete is a function of its constituent material consisting of hydraulic cement (Portland cement), fine aggregate, coarse aggregate, water, and added material (admixture or additive) (Nasional, 2004). The advantage of using concrete is that it has a broader surface so that it can absorb more water and be able to keep soil moisture longer.

\section{Bentonite}

Bentonite is a type of clay that primarily contains more than $85 \%$ montmorillonite with minerals such as calcite, quartz, feldspars, dolomite, and other minerals (Kusrini, 2018). Based on the type, bentonite is divided into two, namely Na-Bentonite and $\mathrm{Ca}$ Bentonite. Comparison between $\mathrm{Na}^{+}$ cations and $\mathrm{Ca}^{+}$cations contained therein is quite high, and the colloidal suspension has a pH of 8.5 to 9.8 (Lim et al., 2013), Figure 3. shows the bentonite powder. Figure 4. shows the chemical structure of the bentonite powder.

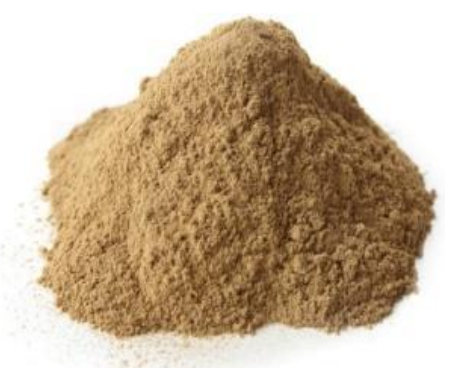

Figure 3. Bentonite powder

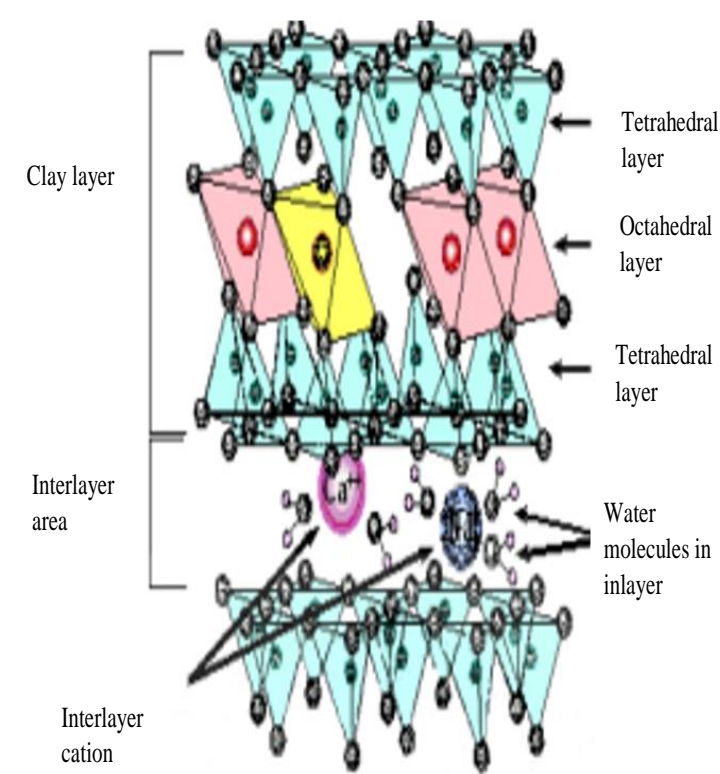

Figure 4. Structure of bentonite (Naswir et al., 2019)

\section{Coconut fibers}

Coconut fiber is one of the bio-mass that is easily obtained and utilized because it can hold the water content and chemical elements of fertilizers and can neutralize the acidity of the soil. Coconut fibers consist of fiber (fiber) and cork (pitch), which connects one fiber to another fiber. Coconut fibers consist of $75 \%$ fiber and $25 \%$ cork. Nutrient content that is owned by coconut fibers, either macro or micro, turns out to be needed by plants. Coconut fiber contained Macro and micronutrients such as $(\mathrm{P})$ Phosphorus, $(\mathrm{K})$ Potassium, (Na) Sodium, (Mg) Magnesium, (Ca) Calcium (Carrijo et al., 2002). Figure 5. shows the coconut powder used for mixing bentonite.

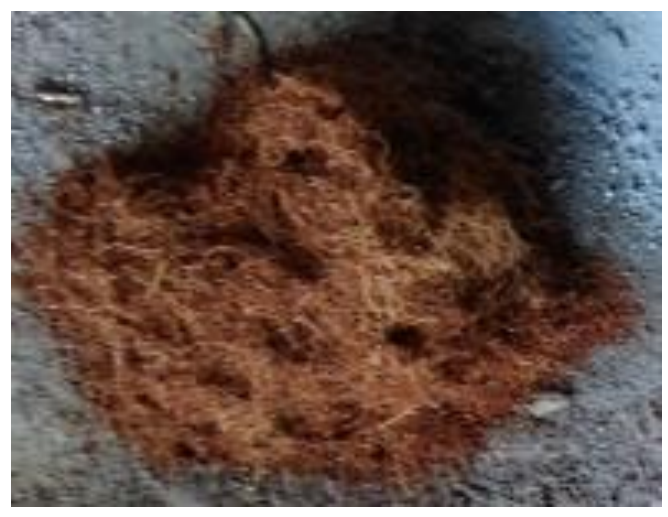

Figure 5. Coconut fiber 


\section{Ufer grounding system}

Ufer grounding is an electrode wrapped in concrete like a building foundation that is in direct contact with the earth to be used as grounding. This concept is based on concrete conductivity and its large surface area so that it can handle very high current loads (Fink \& Beaty, 2006; Umum, 2010). Figure 6. Shows the grounding system using the Ufer grounding method.

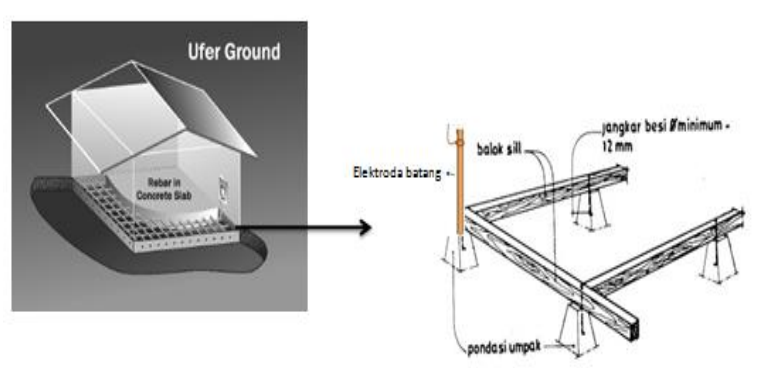

Figure 6. Ufer grounding (Fink \& Beaty, 2006)

\section{RESULTS AND DISCUSSION Pure concrete test results}

Pure concrete testing is the preliminary data from this study, which has been carried out for five months from October 2017 to March 2018 and is measured 14 days in the first month and the fifth month in the morning and evening. That is to find out the testing of grounding prisoners using concrete for a more extended period.

From the graphic can be seen, resistance value in pure concrete is quite stable compared to resistance value from the soil. It means concrete is a good candidate for Ufer grounding materials.

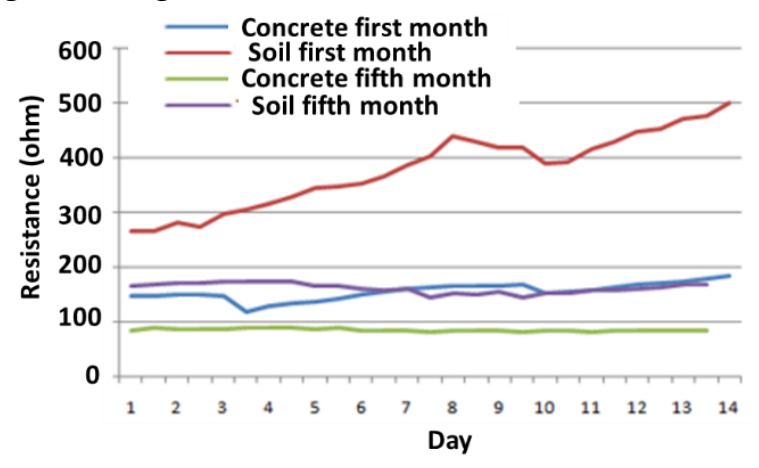

Figure 7. Graphic of the measurement results of pure grounding concrete resistance

\section{Testing of Ground Resistance}

The grounding resistance value following the general electrical installation requirements standard, namely $\leq 5 \Omega$, is used as a security system for devices with a power source for interference caused by short circuits or lightning. To reduce the grounding resistance value, have several methods, one of them is by adding additives material to the grounding system.

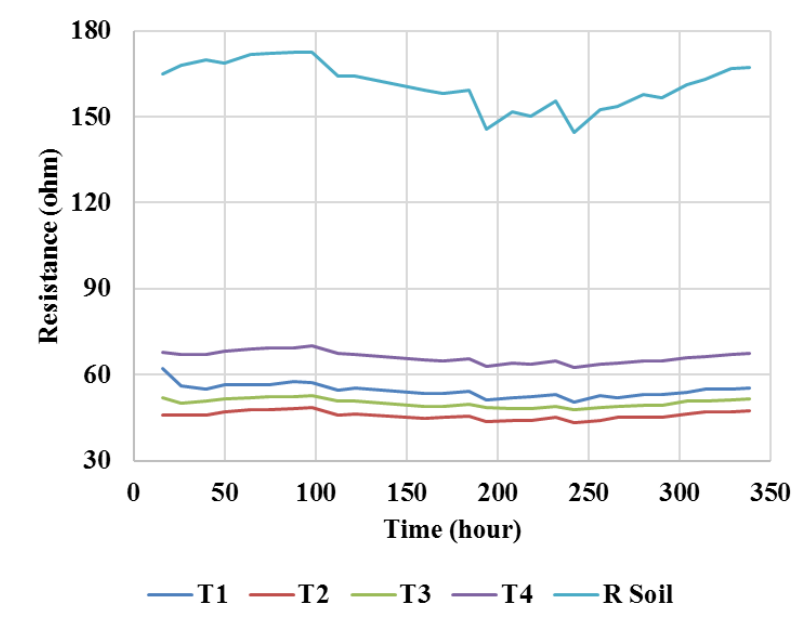

Figure 8. The comparison of measurement results of grounding resistance by the composition of bentonite and coconut fiber.

Figure 8 shows a graph of the comparison of the results of measuring the value of earth resistance (grounding resistance) from concrete variations, which are composed of bentonite and coconut fiber waste. From the figure, it can be seen that the grounding resistance value on the soil looks fluctuating. In contrast, the variation of the concrete mixture of bentonite and coconut fiber waste looks more stable. The average grounding resistance value from the composition of concrete that is composed produces different grounding resistances, namely $54.546 \Omega$ for $\mathrm{T} 1,45.889 \Omega$ for $\mathrm{T} 2,50.192 \Omega$ for $\mathrm{T} 3,66.157$ $\Omega$ for $\mathrm{T} 4$, and $162.2 \Omega$ for grounding resistance of the soil.

\section{Results of Percentage Changes in Grounding resistance Value}

Table 1 shows the percentage change in the value of the most considerable grounding 
resistance, namely with concrete, which is composed of $30 \%$ bentonite, and the addition of $300 \mathrm{~g}$ coconut fiber (T2) is $72 \%$. The difference in the percentage change grounding resistance value from concrete, which is composed of $30 \%$ bentonite from the addition of $150 \mathrm{~g}$ coconut fiber (T3) and $300 \mathrm{~g}$ (T2), is not significant.

Table 1. Percentage change in grounding resistance

\begin{tabular}{ccc} 
value & & \\
\hline Item & $\mathbf{R}(\mathbf{\Omega})$ & Change R $(\boldsymbol{\%})$ \\
\hline T1 & 54,546 & $66 \%$ \\
T2 & 45,896 & $72 \%$ \\
T3 & 50,192 & $69 \%$ \\
T4 & 66,158 & $59 \%$ \\
T0/soil & 161,2 & - \\
\hline
\end{tabular}

\section{Discussion}

Ufer grounding is an electrode wrapped in concrete like a building foundation that is in direct contact with the earth to be used as a grounding resistance system. Concrete is composed of materials in the form of cement, sand, and gravel with a ratio of 1: $2: 4$, where cement itself is composed of several ingredients, namely, as shown in table 2 .

Table 2. Chemical Composition of Portland Cement

\begin{tabular}{lc}
\hline \multicolumn{1}{c}{ Oksida } & Percent $(\%)$ \\
\hline Calcium $(\mathrm{CaO})$ & $60-65$ \\
Silica $\left(\mathrm{SiO}_{2}\right)$ & $17-25$ \\
Aluminum $\left(\mathrm{Al}_{2} \mathrm{O}_{3}\right)$ & $3-8$ \\
Iron $\left(\mathrm{Fe}_{2} \mathrm{O}_{3}\right)$ & $0,5-6$ \\
Magnesium $(\mathrm{MgO})$ & $0,5-4$ \\
Sulfur $\left(\mathrm{SO}_{3}\right)$ & $1-2$ \\
$\left(\mathrm{Na}_{2} \mathrm{O}+\mathrm{K}_{2} \mathrm{O}\right)$ & $0,5-1$ \\
\hline
\end{tabular}

Source: (Tjokrodimulyo, 2007).

Table 2. the main ingredients of cement are lime and silica (clay). Limestone is the primary source of compounds of calcium carbonate $\left(\mathrm{CaCO}_{3}\right)$. Therefore, when cement is made as one of the concrete forming materials, it will increase $\mathrm{Ca}^{+2}$ levels while $\mathrm{CO}_{3}{ }^{-2}$, and if it reacts with $\mathrm{H}_{2} \mathrm{O}$ to $\mathrm{H}_{2} \mathrm{CO}_{3}$, it can eventually break down into $\mathrm{CO}_{2}$ and water vapor.

The concrete structure that contains cement, creates concrete pore spaces, especially water-binding pores which can reduce resistance through the role of water as an electrolyte. In contrast, clay is the primary source of silica compounds. Silica compounds can absorb large amounts of water because they have a large surface and large pore volume. Also, when concrete becomes a solid object, it will have absorption characteristics that can absorb water for a long time and maintain substances around it so that it can retain the moisture in the soil (Badan Standarisasi Nasional, 2004).

The coconut fiber waste is used to increase water absorption and compressive strength of the concrete so that the grounding resistance value will be better than without the addition of coconut fibers. The addition of coconut fiber waste must be limited because it will affect the compressive strength of the concrete itself. The best addition of coconut fiber waste is $0 \%-3 \%$ of the concrete volume. In this study, the amount of addition of coconut fiber waste, which must be limited to $1.5 \%$ is $\pm 316 \mathrm{~g}$. The addition of coconut fiber waste was varied to $0.75 \%$ and $1.5 \%$ in mixing electrodes with bentonite $30 \%$ of the amount of cement. From the addition of the two variations of coconut fiber addition, we should know the best mixture of coconut fiber waste. From the results of measurements obtained by the addition of $30 \%$ bentonite from the amount of cement and coconut fiber waste of $1.5 \%, 300 \mathrm{~g}$ mixed into the concrete has the best value of detention, namely the value of the average resistance $45,896 \Omega$.

Based on the results using concrete can reduce the grounding resistance value significantly, and adding bentonite effectively decreases the grounding resistance. The results are because concrete and bentonite have characters good in absorbing water.

Good bentonite depends on the chemical content, water absorption rate, swelling ability, resistivity, and density (Lim et al., 2013). Bentonite is a type of material with a primary component that is smectite and its physical properties to be determined by the smectite minerals (Ralph \& Guven, 1978). It is montmorillonite and hygroscopic clay, which is characterized by an octahedral sheet 
of aluminum atoms being infixed between two tetrahedral layers of silicon atoms (Özcan \& Özcan, 2004). It has net negative electric charge due to the isomorphic substitution of $\mathrm{Al}^{3+}$ with $\mathrm{Fe}^{2+}$ and $\mathrm{Mg}_{2+}$ in the octahedral sites and $\mathrm{Si}_{4+}$ with $\mathrm{Al}_{3+}$ in the tetrahedral sites and is balanced by the cations such as $\mathrm{Na}+$ and $\mathrm{Ca} 2+$ located between the layers and surrounding the edges (Önal \& Sarikaya, 2007). Natural bentonite has a $\mathrm{pH}$ of 8 to 10 when hydrated with water. It is hydrophilic, as it is strongly hydrated by water (Shen, 2001). This reveals why bentonite has great water absorption capability. Water absorption of bentonite occurs using diffusion and capillary suction (Borgesson, 1985). Also, it also able to retain water or rather moisture content for a considerable period at atmospheric pressure. Once water is absorbed, it can expand up to several times its original volume. However, this water retention and swelling capacity of bentonite are dependent on temperature and pressure (Villar \& Lloret, 2004).

\section{CONCLUSION}

The conclusions are the lowest grounding resistance values are $45.896 \Omega$ at concrete + $30 \%$ bentonite and the addition of coconut fiber waste $1.5 \%(300 \mathrm{~g})$, the grounding resistance value is 3.5 times smaller than the grounding resistance values from the soil. Adding bentonite and coconut fiber can decrease the grounding resistance values. However, the value still far from the standard $(5 \Omega)$. In the future, the research about the grounding system is needed to face global climate change and urbanization.

\section{ACKNOWLEDGMENT}

The researchers appreciate the support provided for this work by faculty of engineering, university of Lampung. This work was also partially supported by the postdoctoral of environment science.

\section{AUTHOR CONTRIBUTIONS}

YM and DP concepting and reviewing literature. AU, and DD develop product.
MM, YM and AR collected, analysed data. $A R$ reviewing literature.

\section{REFERENCES}

Al-Ammar, E., Khan, Y., Malik, N., \& Wani, N. (2010). Development of low resistivity material for grounding resistance reduction. IEEE International Energy Conference Efwfmpqnfou, 35(1), 700-703.

Borgesson, L. (1985). Water flow and swelling pressure in non-saturated Bentonite-Based Clay Barriers. Engineering Geology, 21(3-4), 229237.

Fink, D. G., \& Beaty, H. W. (2006). Standard Handbook for Electrical Engineers. (15th ed.). New York City: McGrawHill.

Ghania, S. M. (2019). Grounding systems under lightning surges with soil ionization for high voltage substations by using two layer capacitors (TLC) model. Electric Power Systems Research, 174(1), 1-12. https://doi.org/10.1016/j.epsr.2019.105 871

Gomes, C., Ab Kadir, M. Z. A., Kottachchi, C. L., \& Lim, S. C. (2014). Industrial wastes and natural substances for improving electrical earthing systems. International Journal of Electrical Engineering, 21(2), 39-47. https://doi.org/10.6329/CIEE.2014.2.01 Halim, N. H., Hairuddin, M. F., Arshad, S. N. M., Isa, M., Adzis, Z., \& Khang, A. W. Y. (2019). Analysis on topology of grounding system using bentonite and coconut husk as additive material. Universal Journal of Electrical and Electronic Engineering, 6(5), 50-58. https://doi.org/10.13189/ujeee.2019.06 1506

Jin-rong, W., \& Yong-ming, D. (2008). The Application of Conductive Concrete in the Grounding Network Reconstruction of Baisha Hydropower Station. CNKI.

Kusrini, N. (2018). Pemanfaatan bentonit, kapur dan limbah puing bangunan 
untuk meningkatkan kapasitas tanah tropika dalam menurunkan resistansi grounding. Universitas Lampung.

Lehmann, J., Coumou, D., \& Frieler, K. (2015). Erratum to: increased recordbreaking precipitation events under global warming. Climatic Change, 132(4), 517-518. https://doi.org/10.1007/s10584-0151466-3

Lim, S. C., Gomes, C., \& Kadir, M. Z. A. A. (2016). Behaviour of a new material that improves Ufer grounding practice. $J$. Electrial Systems, 12(2), 291-300.

Lim, S. C., Gomes, C., \& Ab Kadir, M. Z. A. (2013). Characterizing of bentonite with chemical, physical and electrical perspectives for improvement of electrical grounding systems. International Journal of Electrochemical Science, 8(9), 1142911447.

Ma, H., Hou, D., Liu, J., \& Li, Z. (2014). Estimate the relative electrical conductivity of C-S-H gel from experimental results. Construction and Building Materials, 71(1), 392-396. https://doi.org/10.1016/j.conbuildmat.2 014.08 .036

Martin, Y., Permata, D., Despa, D., \& Wiyoto, Y. L. (2019). The use of physically activated and soil composed bentonite as environment friendly for grounding resistance. IOP Conference Series: Earth and Environmental Science, 245(1). https://doi.org/10.1088/17551315/245/1/012004

Martin, Y. (2019). Composition of mixing gypsum additives as environmentally friendly material in tropical soil to reduce grounding resistance. IOP Conference Series: Earth and Environmental Science, 314(1), 1-8. https://doi.org/10.1088/17551315/314/1/012019

Nasional, Badan Standardisasi. (2002). Tata Cara Pencampuran Beton Ringan Dengan Agregat Ringan. Jakarta:
Departemen Pekerjaan Umum.

Nasional, Badan Standardisasi. (2008). Cara Uji Berat Jenis dan Penyerapan Air Agregat Halus. Jakarta: Departemen Pekerjaan Umum.

Nasional, Badan Standarisasi. (2004). Semen Portland Komposit. Jakarta: Departemen Pekerjaan Umum.

Naswir, M., Gusti Wibowo, Y., Arita, S., Hartati, W., \& Septiarini, L. (2019). Utilization of activated bentonite to reduce nitrogen on palm oil mill. International Journal of Chemical Sciences, 3(4), 89-92. https://www.researchgate.net/publicatio $\mathrm{n} / 335738640$

Ogunbode, C. A., Demski, C., Capstick, S. B., \& Sposato, R. G. (2019). Attribution matters: Revisiting the link between extreme weather experience and climate change mitigation responses. Global Environmental Change, 54(1), 31-39. https://doi.org/10.1016/j.gloenvcha.201 8.11.005

Önal, M., \& Sarikaya, Y. (2007). Preparation and characterization of acid-activated bentonite powders. Powder Technology, 172(1), 14-18. https://doi.org/10.1016/j.powtec.2006.1 0.034

Özcan, A. S., \& Özcan, A. (2004). Adsorption of acid dyes from aqueous solutions onto acid-activated bentonite. Journal of Colloid and Interface Science, 276(1), 39-46. https://doi.org/10.1016/j.jcis.2004.03.0 43

Rahmat, A., \& Mutolib, A. (2016). Comparison of air temperature under global climate change issue in Gifu City and Ogaki City, Japan. Indonesian Journal of Science and Technology, 1(1), 37-46. https://doi.org/10.17509/ijost.v1i1.2212 Ralph, E. G., \& Guven, N. (1978). Bentonites: Geology, mineralogy, properties and uses (Developmen). Amsterdam: Elsevier Science.

Shen, Y. H. (2001). Preparations of 
organobentonite using nonionic surfactants. Chemosphere, 44(5), 989995. https://doi.org/10.1016/S00456535(00)00564-6

Sun. (2001). Application of Conductive Concrete in Grounding Grid in Substation. High Voltage Engineering, 10(1).

Hutauruk, T. S. (1991). Pengetanahan netral sistem tenaga dan pengetanahan peralatan. Erlangga.

Tian, X., Hu, H., \& Chen, B. (2012). An Environment-Friendly Conductive Concrete. Earth Science Research, 1(2), 185-188. https://doi.org/10.5539/esr.v1n2p185

Tjokrodimulyo, K. (2007). Teknologi Beton. Biro Penerbit Jurusan Teknik Sipil Fakultas Teknik Ugm.

Umum, D. P. (2010). Spesifikasi umum bidang jalan dan jembatan, badan penelitian dan pengembangan $P U$. Jakarta: Departemen Umum.

Villar, M. V., \& Lloret, A. (2004). Influence of temperature on the hydro-mechanical behaviour of a compacted bentonite. Applied Clay Science, 26(1-4 SPEC. ISS.), 337-350. https://doi.org/10.1016/j.clay.2003.12.0 26 